\title{
Confronting the Perils of Globalization: Nicaraguan Banana Workers' Struggle for Justice
}

\author{
Ethan Grundberg
}

As our bus finally entered the city of Managua in early April 2005 after a 10-hour drive from San Salvador, I peered out the window in an effort to locate the numerous landmarks that the stout Nicaraguan man sitting next to me was describing. We passed the massive statue of Augusto Cesar Sandino that towered over the city, the Taiwanese-funded outdoor amphitheater, the giant Plaza de la Fe constructed in honor of Pope John Paul II's 1996 visit, the Rúben Darío National Theater, and finally the modest National Assembly. Across the street from the Assembly in what normally was a desolate field, thousands of campesinos crouched under tents made of black plastic and swung in their brightly colored hammocks behind giant banners pleading for the protection of Law 364 and demanding fair compensation for exposure to a chemical called Nemagon. Gustavo informed me that this was not the first time that the former banana plantation workers had marched from their homes in the northwestern region of Chinandega to Managua in their long struggle to hold transnational corporations (TNCs) accountable for damages resulting from exposure to the toxic chemical. Over the next month and a half, I would regularly find myself crouched beneath the sweltering black plastic tents listening to the humble workers donning torn plaid shirts and wide-brimmed cowboy hats describe how they had managed to forge a popular national movement to confront some of the world's most powerful corporations.

The movement of former banana plantation workers began in the 1990s as a legal struggle for indemnity from TNCs responsible for the production and use of Nemagon. After failing to obtain a satisfactory compensation through the courts, workers mobilized to pressure the Nicaraguan government to provide the movement with legislative support. The workers were successful in their efforts and reissued numerous lawsuits against the TNCs in both Nicaraguan and U.S. courts. Though these cases are still in trial, the movement has succeeded in obtaining numerous material concessions from the government and in rallying popular support in Nicaragua.

The experience of the former Nicaraguan banana plantation workers' movement illuminates the paradoxical effects that deepening globalization has had on rural workers' agency. Though there is little agreement among theorists as to its precise definition, globalization can be broadly characterized as, "the ways in which previously distant parts of the world have become connected in an historically unprecedented manner, such that developments in one part of the world are now 
able to rapidly produce effects on geographically distant localities. This in turn has made it possible to begin to imagine the world as a single, global space linked by a wide array of technological, economic, social and cultural forces." In the case of the Nicaraguan banana workers, globalization has created the conditions in which a U.S.-produced toxin can be utilized by TNCs operating in the global south with little regard for the human health impacts on a seemingly infinitely replaceable labor pool. However, globalization has also ushered in an era in which grassroots labor and social justice non-governmental organizations can bridge cultural, physical, and logistical barriers to disseminate information and unite geographically disparate groups to network for a common cause. The emergence of a "globalization from below," a model of globalization that "supports individuals and groups using the new technologies to create a more multicultural, egalitarian, democratic, and ecological world," has enhanced the ability of workers throughout the global south to shape international law and confront their systematic exploitation. ${ }^{2}$

Though the Nicaraguan banana workers are engaged in such an international confrontation, their movement bears little resemblance to popular globalization theorists' vision of the politics of "globalization from below." Unlike traditional social mobilization that has focused on organizing at the national level and engaging the nation-state, some theorists argue that "globalization from below" will seek "to challenge the power of the global elite by accumulating counter-hegemonic forces beyond national and regional borders; to challenge that power from within an expanding transnational civil society." The creation of a "global multitude" resulting from the demand that "the juridical status of the population be reformed in step with the real economic transformations of recent years" is perceived as necessary to confront the actors of global capitalism. ${ }^{4}$ Even the "Lilliputian strategy," which promotes the global coordination of decentralized and autonomous popular movements, assumes that social mobilizations will transcend the confines of the nation to confront the new global elite. ${ }^{5}$ This focus on transnationalizing social movements seems to be the result of the perceived obsolescence of the nation-state as a category of analysis. At a time in which neo-liberalism and global capitalism have left skeletal governments in their paths, it is understandable that one would argue, "the neo-liberal state retains essential powers to facilitate globalization but it loses the ability to harmonize conflicting social interests within a country, to realize the historic function of sustaining the internal unity of a nationally conceived social formation, and to achieve legitimacy." ${ }^{\prime 6}$ However, the movement of former banana plantation workers in Nicaragua demonstrates a powerful alternative to a transnational globalization from below that instead champions the traditional nationstate and popular nationalism as unifying forces against foreign exploitation. By employing innovative tactics that simultaneously appealed to Nicaraguan society and pressured elected representatives, the former banana workers were able to gain valuable support from the government. The Nicaraguan government, a clear example of a minimalist neo-liberal state, has effectively reasserted its traditional 


\section{Ethan Grundberg}

powers of sovereignty and self-determination to challenge the declaration of the death of the nation-state.

The movement's success in gaining the support of the Nicaraguan government can be explained by two factors. First, the decision can be viewed as a continuation of Nicaragua's historical narrative of resistance to foreign intervention. ${ }^{7}$ From President Zelaya's opposition to U.S. pressure to concede territory for the construction of an inter-oceanic canal in the early 1900s, to Augusto Cesar Sandino's anti-imperialist campaign against the U.S. Marine occupation from 19271933, to the overthrow of the U.S.-supported Somoza regime by the Sandinistas in 1979, many Nicaraguans understand their history as a perpetual quest for selfdetermination and against foreign interest. ${ }^{8}$ The former banana plantation workers were able to forcibly associate with this narrative of anti-imperialism to garner popular and governmental support.

Part of the workers' success in associating with Nicaragua's historical narrative was dependent on the second factor: the workers' effective creation of spectacle to assert their citizenship and awaken a latent popular nationalism infused with the powerful anti-imperialist ideology of Sandinismo. As anthropologist Daniel Goldstein notes, "The spectacle, then ... is also about being seen: calling attention to oneself or one's group by means of public display. This is particularly important in urban settings, in which people are marginalized or otherwise rendered invisible in the public eye, yet are in close geographical proximity to the loci of official power." By physically camping in front of the National Assembly in Managua and threatening violent tactics such as self-immolation and crucifixion while also carrying the Nicaraguan flag at the head of each march and employing the rhetoric of Sandinismo, the banana workers forced themselves into the public eye and cultivated a powerful association with Nicaraguan nationalism that resonated strongly with much of society. As a result of constructing their movement as an embodiment of nationalism, the workers were able to force the government to overcome its neo-liberal obsolescence and challenge the hegemony of capital in order to maintain popular legitimacy. The struggle of the Nicaraguan banana workers confirms Marc Edelman's assertion that, "even after more than a decade of neoliberalism, state agencies remain absolutely central points of reference, foci of demands, and sites of struggle, despite the undermining of traditional power centers that accompanies economic globalization." ${ }^{10}$ From a small field across from the National Assembly in Managua, the workers have illustrated the continuing potency of popular nationalism in defiance of an increasingly transnational world.

\section{The Beginnings of a Toxic Legacy}

U.S. banana businesses began to develop along Nicaragua's Atlantic coast in the mid-1890s in response to efforts by President José Santos Zelaya to attract foreign investment and modernize the economy. Between 1909 and 1929, U.S. 
business investment in Nicaragua doubled to $\$ 20$ million largely as a result of an influx of banana corporations, such as the Cuyamel Fruit Company, Bragmans Bluff Lumber Company (a subsidiary of Standard Fruit), and the Bluefields Company. However, the banana industry failed to develop as robustly in Nicaragua as it had in other Central American countries because of less productive soils, an early outbreak of Panama disease, and eventually the socio-political turmoil caused by Augusto Sandino's 1926 rebellion. ${ }^{11}$ The banana industry slowly withered after the onset of the Great Depression until production was so low in 1943 that the government neglected to issue a report on the sector. ${ }^{12}$

However, Standard Fruit Company renewed its interest in developing a banana industry in Nicaragua after a 1944 soil study revealed promising conditions on the Pacific coast near Chinandega. Standard's resident manager H.D. Scott obtained a land concession that same year intended for banana production. ${ }^{13}$ United Fruit Company followed Standard's lead and began operations on the Pacific coast in 1960. Although production numbers remained low through the 1960s, Standard Fruit maintained significant exports averaging approximately 5.7 million crates (about 40 pounds each) per year earning around \$5 million USD annually between 1972 and 1979. ${ }^{14}$ However, U.S. banana corporations dramatically decreased production in Nicaragua in response to the triumph of the Sandinista revolution in 1979. Fearful of increasing socio-political instability and disturbed by the creation of a nationalized banana company, the Empresa Nicaragüense del Banano (BANANIC), Standard Fruit essentially abandoned the country in 1982. ${ }^{15}$

Part of the temporary success that U.S. companies had in reviving the Nicaraguan banana industry in the 1960s resulted from their introduction of new and more powerful agro-chemicals. Transnational corporations first introduced synthetic agro-chemicals to Central America in the 1940s in order to combat pests and plant diseases and increase crop yields. The use of such chemicals spread quickly over the next several decades, reaching consumption levels of approximately 66 million pounds per year and constituting a \$165 million market in the region in the 1970s. In Nicaragua, agro-chemicals were first used to help spur the cotton boom of the 1940s and '50s, but eventually spread to other agricultural crops like sugar cane and bananas. ${ }^{16}$ After containing the massive outbreak of Panama disease in the 1940s with the help of synthetic fumigants, banana corporations encountered a new infestation in the 1960s: tiny worms called nematodes. The worms fed on the roots of banana trees, destroying the plant in the process. ${ }^{17}$ Standard Fruit Company estimated that nematodes had reduced production by as much as 25 to 35 percent on its plantations in Costa Rica and Honduras in the late 1960s. In response, the corporation began to experiment with a number of nematicides, agro-chemicals that control nematode populations, including Nemacur, Terracur, Lannate, and DBCP. ${ }^{18}$ Most fruit companies soon settled on DBCP and began using the nematicide on banana plantations throughout Latin America.

DBCP, or 1,2-dibromo-3-chloropropane, was discovered independently by

Iowa Historical Review 


\section{Ethan Grundberg}

Shell and Dow Chemical Companies in 1951. Before releasing their products on the market, each corporation conducted a series of toxicological tests that exposed lab animals to the agro-chemical to determine its potential health impact on humans. These tests, conducted from 1954 to 1955, showed that rats exposed to the chemical experienced "retarded growth, organ damage, and undersized testes" even at low doses. Despite these initial test results, Shell began to produce DBCP in 1956 in preparation for its introduction to the commercial market using the name Nemagon, followed by Dow in 1957 under the name Fumazone. ${ }^{19}$

Dow and Shell continued testing DBCP on lab animals throughout the 1950s. Further testing confirmed the initial findings, concluding, "Liver, lung and kidney effects might be expected... Testicular atrophy may result from prolonged repeated exposure." ${ }^{20}$ However, Shell Chemical Company intentionally withheld some of the toxicological test results and recommended safety precautions while understating other potential hazards associated with the agro-chemical in its product data summary report that was submitted to the U.S. Department of Agriculture in 1961. In 1964, Nemagon and Fumazone were both approved for commercial sale provided the chemical packaging displayed mild warning labels such as "Do not breathe vapors" and "Do not contact with skin and eyes." 21 Within months, $\mathrm{DBCP}$ was being used in the United States on over 40 different agricultural crops, including soybeans, pineapples, nuts, and cotton. ${ }^{22}$

Standard Fruit and other banana companies began to use DBCP on a large scale on plantations across the globe beginning in 1969, with the first registered use in Nicaragua recorded on August 14, 1973. ${ }^{23}$

Though they were not the most effective at combating nematode infestations, the DBCP products proved to be the most cost efficient due to their 40 to 60 percent lower cost than the other nematicides. ${ }^{24}$ In order for the chemical to be effective, DBCP had to be absorbed by the soil and come into physical contact with nematode populations. Plantation managers eventually discovered two primary methods of applying the nematicides to the sprawling rows of banana plants. First, workers used long devices imported from Taiwan, known as "kyoritzu," that were comparable to oversized syringes to inject a diluted solution of water and DBCP as close to the banana plant root as possible. Teams of four to six workers would cover approximately three hectares of plants daily using this method. ${ }^{25}$ The other popular application method used on plantations involved distributing the chemical through the irrigation system and aspersion towers. While this second method was more efficient than the manual injection of DBCP, it could only be used given the appropriate dry soil conditions, lack of wind, and stable temperature range. Under these conditions, DBCP was typically mixed into the irrigation system at the end of the working day and allowed to saturate the plants and soil overnight. ${ }^{26}$

Both application methods resulted in excessive exposure of workers and their families to the nematicide. Banana workers using the direct injection method were frequently splattered with DBCP residue when the liquid encountered obstacles in 
the ground like roots or rocks. Since these workers rarely wore protective clothing, the chemical would be absorbed through the skin, respiratory tract, and into workers' clothing. Workers were also regularly splashed with the liquid chemical and exposed to its fumes when they were required to manually dilute the chemical throughout the day and pour the water-DBCP mixture into their kyoritzu. When the chemical was applied through the irrigation system overnight, everyone living around the plantation would inhale DBCP's vapors the following morning as the sun heated the earth creating a layer of evaporated liquid residue trapped by the thick canopy of banana leaves. Former banana plantation workers tell stories of waking up to thick clouds of pungent fumes enveloping both the fields in which they worked and their homes that were situated on the periphery of the plantations. ${ }^{27}$ The irrigation application method also resulted in higher contamination of rivers, creeks, and other drinking water sources. ${ }^{28}$ Furthermore, workers and their families ingested chemical residues by eating food produced and/or prepared in close proximity to DBCP. $^{29}$

Although the workers and their families were unaware of it at the time, their repeated exposure to DBCP posed a serious health risk. The mild cautionary warnings provided on the barrels of DBCP products were of little help to the workers using the nematicides. Angel Espinoza, a Nicaraguan lawyer representing victims of DBCP exposure, explained bluntly that the warning labels "were written in English, and the banana workers didn't know English, and even in English the labels only advised in general terms that the chemical could be dangerous." 30 Tests conducted on the product in the three decades since its introduction to Nicaragua have begun to illuminate just how dangerous the product really was. In addition to being categorized as "possibly carcinogenic to humans" by the International Agency for Research on Cancer, DBCP has been linked to kidney damage, liver damage, respiratory tract toxicity, testicular damage, and male infertility. ${ }^{31}$

In response to these test results and the discovery of rampant male infertility in a California DBCP production plant, the U.S. Environmental Protection Agency (EPA) banned general use of the potent nematicide in 1979. However, transnational chemical corporations were permitted to continue producing and exporting DBCP to countries with less stringent environmental and labor regulations. ${ }^{32}$ Although United Fruit Company stopped use of DBCP after the EPA ban, other transnational fruit corporations like Standard Fruit Company continued to use the product into the 1980s in an effort to avoid production and profit losses. ${ }^{33}$ In Nicaragua, leftover stockpiles of DBCP were used on both nationalized and private banana plantations until 1985. The chemical was not formally prohibited until $1993 .^{34}$

As a result of the prolonged use of the toxic nematicide, thousands of former banana plantation workers now suffer the agonizing symptoms of DBCP exposure. For example, Pedro Lezama, a 64-year-old former plantation worker, blames Nemagon for his sterility, asthma, migraines, blurred vision, and chronic body aches. Fifty-two-year-old Teléforo López, a former Chinandegan plantation 


\section{Ethan Grundberg}

worker, suffers from over 30 cancerous tumors in his legs, abdomen, thorax, neck, and back. Julio César Peralta, the eight-year-old son of a plantation worker, suffers from physical deformities, hemorrhaging in his eyes and nose, and a variety of skin problems. ${ }^{35}$ Similar health problems afflict thousands of former Chinandegan banana plantation workers and their families who now blame DBCP for their ailment. According to another victim of DBCP exposure, Victorino Espinales, the effects of the chemical's use in Nicaragua have been devastating. "We've arrived at the conclusion that this problem is one very similar to the bombs of Hiroshima and Nagasaki: 25 years later we are suffering the consequences of this deadly product." ${ }^{36}$

\section{The Fight to be Heard in Court}

Twenty years after the last drops of Nemagon were injected into the soils of Chinandega, a controversial movement of over 20,000 former banana plantation workers emerged to demand indemnity from the transnational corporations responsible for their exposure to the "Dew of Death." 37 The source of the numerous health problems plaguing the former banana plantation workers was not known until the mid-1980s. The man largely responsible for unearthing the culprit agro-chemical was Victorino Espinales Reyes, an ex-Sandinista politician and charismatic leader of ASOTRAEXDAN (the Association of Workers and Former Workers Affected by the Pesticide Nemagon) founded in 2000. Espinales became active with the Frente Sandinista de Liberación Nacional (FSLN) when he was only in his late teens. In 1971, he was assigned to clandestinely organize workers on the María Elsa, Elisa y Alfonso Angelina banana plantations in Chinandega. In order to complete his obligation to the revolutionary movement, Espinales became a plantation worker cutting, packaging, and applying pesticides to the bananas that covered much of the region. After the triumph of the Sandinista revolution in July 1979, Espinales remained active in one of the many banana worker unions and led a commission that same year to understand the widespread occurrence of skin infections, vision problems, depression, male infertility, and other ailments within the sector. ${ }^{38}$ However, Espinales would not discover the correlation between DBCP use and these various ailments until 1985. Then working as the President of the Environmental Commission for the National Assembly, Espinales was informed by a group of Costa Rican and Colombian banana worker union leaders that the nematicide that had been applied for years had been linked to many deaths in their countries. ${ }^{39}$ After the Sandinistas were voted out of office in the 1990 elections, Espinales decided to devote himself to organizing those affected by DBCP exposure.

Despite its origins in the Sandinista Revolution, the Nicaraguan movement that developed in the 1990s was largely a response to the powerful Costa Rican movement that had developed in the mid-1980s. Like in Nicaragua, banana organizers began to notice an astonishing increase in the prevalence of certain health problems 
in communities of former banana workers. The first cases of male infertility linked to DBCP exposure were discovered in Costa Rica in 1977. By 1990, some 1,500 Costa Ricans had been diagnosed as infertile as a result of exposure to Nemagon. ${ }^{40}$ Costa Rica's National Insurance Institute (INS), the nationalized health insurance company, bore the financial costs of evaluating the workers. In addition, many of the infertile workers began to file for compensation from the state institute under a provision of the Costa Rican Labor Risk Law that provided payment to individuals who had lost their testicles as a result of their occupation. By 1988, about 500 infertile banana workers had received compensation payments between U.S. \$500$\$ 2,000$ from the INS. ${ }^{41}$

The INS compensation was unsatisfactory to some of the Costa Rican workers, especially after hearing that Californian workers who had received compensation after pressing legal charges against Dow and Shell for sterility caused by exposure to DBCP had been awarded up to $\$ 2.8$ million each in the late $1970 \mathrm{~s} .{ }^{42}$ Using connections within the INS, the Costa Rican victims of DBCP exposure were able to contact a Dallas, Texas-based law firm in 1982 to begin legal proceedings in the U.S. Between 1983 and 1990, approximately 400 workers filed suits against Dow Chemical and Shell Oil in U.S. courts ${ }^{43}$ However, the workers were routinely denied access to the U.S. judicial system on the grounds of forum non conveniens, a legal doctrine "which allowed judges to dismiss suits by foreign plaintiffs on the grounds that the forum or court that the plaintiff had chosen was not convenient or proper because the injury or death took place elsewhere." ${ }^{44}$ According to Erika Rosenthal of the Pesticide Action Network, forum non conveniens "has been used as a shield or a way for U.S. corporations to evade liability." "45 Finally, the Texas Supreme Court overturned forum non conveniens in a 5-4 ruling on March 28, 1990. Within two years, Dow Chemical, Shell Oil, Standard Fruit, and Chiquita Brands had settled out of court with 800 Costa Rican workers for approximately $\$ 20$ million, with each individual receiving between $\$ 1,500$ and $\$ 15,000$ after legal fees. ${ }^{46}$

The case of the Costa Rican banana workers established a strong precedent that allowed a class action lawsuit in which some 26,000 workers from Costa Rica, Ecuador, El Salvador, Guatemala, Honduras, Nicaragua, the Philippines, and five other African and Caribbean countries were able to settle out of court in 1997 for $\$ 41.5$ million, with each worker receiving an average of $\$ 1,500 .{ }^{47}$ The Costa Rican movement also acted as a catalyst for individual national movements to develop across the global south, including Nicaragua. After learning of the Costa Rican law suit at a grassroots legal service seminar held in San Jose in September 1992, Álvaro Ramírez, the president of the Nicaraguan Association of Democratic Attorneys, began legal proceedings on behalf of 812 Nicaraguan workers affected by Nemagon. ${ }^{48}$ The case ended in 1997 when Dow Chemical agreed to pay $\$ 22$ million to the Nicaraguans. Tragically, only a fraction of the multi-million dollar settlement trickled down into the pockets of the banana workers. It is estimated that the 812 


\section{Ethan Grundberg}

plaintiffs collectively received only $\$ 143,000$ while the U.S. law firm that filed the case retained an impressive $\$ 21.8$ million. ${ }^{49}$ Additionally, plaintiffs were "forced to sign a document that exonerated the transnationals of further damages caused to the workers and to their children." 50 These settlements were clearly insufficient to compensate for the suffering of the banana plantation workers.

While these settlements were inadequate, non-U.S. workers for TNCs had at least successfully fought for a forum in which to seek justice against their employers. Other foreign workers who had suffered occupational injuries while employed by TNCs, especially the victims of the 1984 Union Carbide chemical plant explosion in Bhopal, India, were anxious to take advantage of legal opening established by the Costa Rican case and further their own case of corporate accountability. ${ }^{51}$ However, the Texas State Legislature prevented such action by reinstating the doctrine of forum non conveniens in $1993 .{ }^{52}$ Workers affected by exposure to Nemagon, as well as the Bhopal victims and others struggling against TNCs across the globe would have to find an alternative route to justice.

In Nicaragua, banana workers responded to the doctrine's reinstatement by seeking redress in the national judicial system. In 1996, Victorino Espinales and other leaders began to lobby the National Assembly to pass a law to provide legal support in future lawsuits brought against the corporations by affected workers. ${ }^{53}$ Nicaraguan law firms also continued collecting medical information in coordination with the movement leaders, such as the 1998 report that revealed that 169 of 500 ex-banana workers surveyed suffered from different types of cancer. ${ }^{54}$ During this period, workers also continued to spread the word of the correlation between Nemagon and various illnesses and organize behind the leadership of Espinales. ${ }^{55}$ However, the movement had little success rallying popular and governmental support.

As a result, the movement that had developed under Espinales began a new more public phase of their struggle. The March 1999 imprisonment of Espinales for allegedly making death threats towards Chinandegan politicians and for threatening the freedom of commerce led the movement to initiate a campaign of direct action. The leader and many of his followers began a hunger strike to protest both Espinales' imprisonment and to bring greater attention to their cause. The flurry of newspaper coverage that resulted from the hunger strike conveniently highlighted the start of a government commission centered in the city of El Viejo, Chinandega, to investigate the impact of Nemagon in the region. ${ }^{56}$

The workers continued their public acts of direct action in November 1999 by organizing what would become the first of four long marches from Chinandega to Managua. The 133-kilometer trek made by several hundred campesinos was intended to highlight the plight of the victims while articulating their demands to the rest of the nation. According to Espinales, the two main goals of the movement were to secure a fair compensation from Standard Fruit Company and Dole and to pressure the Nicaraguan government to establish a permanent health commission 


\section{Confronting the Perils of Globalization}

in the countryside to both study the various ailments of campesinos and provide medical treatment. ${ }^{57}$

After being received by Sandinista representatives of the National Assembly, Espinales and the other workers marched across town to the U.S. Embassy to continue their protest. The workers intended to deliver documents containing medical evidence of the correlation between Nemagon exposure and their illnesses along with a letter to U.S. Ambassador Oliver Garza requesting the support of the U.S. government in their continuing lawsuits against the TNCs. ${ }^{58}$ Though they were unable to meet with Garza, another embassy official met with members of the movement and expressed his support for the workers' right to protest, but did not comment on the U.S. government's position on their struggle. ${ }^{59}$ Though the workers failed to secure the support of the U.S. government during their visit to the embassy, they certainly "began to make themselves heard" to both the Nicaraguan and U.S. governments. ${ }^{60}$ Their shouts of "We Want Justice" and "No More Exploitation by the Transnational Standard Fruit Company" not only helped to raise the consciousness of the general public, but also acted to inform other former Chinandegan banana plantation workers suffering from similar illnesses of the probable link to the toxic nematicide. ${ }^{61}$

The next step in the Nemagon victims' direct action campaign was to rally local support in Chinandega to place greater pressure on the government to provide institutional support to the movement. In the middle of July 2000, approximately 200 former banana and sugar cane workers blocked the main highway at the entrance to the state capital demanding support for an "Emergency Law of Pesticides" that would provide legal assistance to the Nemagon victims, as well as other local issues such as the titling of disputed land in the region. After three days of sustaining the blockade, the Chinandegan police arrested Espinales and three other leaders while allegedly confiscating 18 machetes, various metal pipes, and 130 wooden clubs (which the workers argued were used for coffee grinding) from the protesters. The demonstration was then moved to the police headquarters, where some 100 women affected by Nemagon announced the beginning of a hunger strike in protest of Espinales' imprisonment. Espinales and the other movement leaders were released later that afternoon and the police promised to respect the workers' right to protest, so long as they stopped their blockade of the highway. ${ }^{62}$ Though their rights of assembly and expression were preserved, the workers failed to secure government support for their struggle.

Following their demonstration in Chinandega, Espinales and his followers decided to return to Managua to continue pressuring the government to provide them with medical attention and legal assistance in their cases against the producers and users of DBCP. The protesters set out on the week-long journey from Chinandega to Managua in late August and arrived in front of the National Assembly on September 1, 2000, where they began to voice their demands and attract media attention. First, many of the protesters participated in a seven-day long hunger strike to pressure 


\section{Ethan Grundberg}

legislators to help their cause. However, 16 protesters involved in the hunger strike were forced to abandon the demonstration and return to Chinandega after nearly dying as a result of the combination of their pesticide-related illnesses and malnutrition, while four others were hospitalized in Managua. ${ }^{63}$

As a result of their actions, the workers drew the attention of Human Rights Ombudsman Benjamín Pérez, who visited the protest camp to meet with Espinales and other ex-banana workers. After the meeting, Pérez noted, "The real battle and solution to the problems that are impacting the campesinos affected by Nemagon are inside the National Assembly" and pledged to meet with the Assembly's directorate to encourage the passage of a proposed bill that would provide legal aid to the workers. ${ }^{64}$ Despite the support of Pérez, the National Assembly continued to delay the approval of the bill, likely fearing political and economic ramifications from the U.S. government.

In response to the continued inaction, Espinales and the several hundred other protesters issued an ultimatum to the Nicaraguan legislators on September 5,2000 , to pass the law that had been proposed four years earlier in the coming 48 hours, or the workers would stage a nude march through Managua "to show the parliamentarians that we are better citizens than they are, and more true to our word." ${ }^{65}$ More tangibly, the "march of the naked" would have forced the public to accept the physical fragility and weakness of the hundreds of campesinos suffering from cancers and skin diseases. The workers hoped their willingness to sacrifice humility would shame the Nicaraguan government and the TNCs, both alienated from mortal impacts of pesticide use, into taking action.

Finally on November 23, 2000, the National Assembly made the historic decision to pass legislation to provide legal support to the former banana plantation workers. ${ }^{66}$ Law 364, the "Special Law for the Procedure of Law Suits Filed by those Affected by the Use of Pesticides Made with DBCP (Nemagon)," contained a number of provisions intended to circumvent the legal obstacle of forum non conveniens. It also established a minimum allowable settlement in order to avoid the outcome of the Costa Rican-led class action lawsuits of the 1990s, which resulted in only meager payouts for the affected workers. According to Bayardo Izaba, a lawyer with the Nicaraguan Center for Human Rights, the law was so helpful because it "establishes a very rapid procedure for handling judgments that workers bring before the courts." ${ }^{67}$

Specifically, Law 364 mandates that foreign companies must provide a minimum payment of one hundred thousand dollars for each case brought against them in Nicaragua within 90 days to pay for legal expenses and to ensure that workers will receive compensation if the court rules against the TNC. Under the law, the money is returned if the foreign corporation wins the case. ${ }^{68}$ Most importantly, the law notes that TNCs must forfeit the right to invoke the doctrine of forum non conveniens if they refuse to pay the stated sum or hear a case in Nicaraguan courts. ${ }^{69}$ Thus, workers who are denied access to U.S. courts on the basis of forum 
non conveniens have a chance of winning a just compensation by suing the TNCs in Nicaraguan courts, whereas previously TNCs could simply refuse to respect the jurisdiction of the Nicaraguan judicial system after being found liable for damages. Juan J. Dominguez, a U.S.-based lawyer representing some of the thousands of Nicaraguan Nemagon victims in court, noted the importance of Law 364 by stating "for the first time, there's a law in the country where the tort occurred. It provides defendants with a forum to defend themselves. They can choose either forum and there are adequate laws and measure of damages." 70

\section{Overwhelming Obstacles on the Road to Justice}

Though Espinales and the other victims of Nemagon exposure made great progress toward holding the TNCs accountable with the passage of Law 364 , the universal perils of corporate globalization threatened the movement's legislative victory. In this era of neo-liberal fundamentalism, where international standardization and market supremacy have achieved status of infallibility, the Nicaraguan government's decision to provide institutional support to the workers was considered blasphemous by globalization's most vociferous advocates: TNCs and the U.S. government. Such a challenge to the disparity between the international rights of corporations and those of workers threatened to set a dangerous precedent that undermined status quo international power relations. Thus, the proponents of globalization attempted to exploit their position of relative privilege in the global political-economic arena to pressure the Nicaraguan government to reconsider the new law.

After the passage of Law 364, the targeted TNCs immediately launched a campaign to undermine the legislation. One Dow Chemical spokesperson noted "Special Law 364 contains numerous provisions that simply make it impossible for Dow (or the other targeted companies) to receive a fair trial in Nicaraguan courts. In fact, Law 364 ensures the entry of judgments that are completely inconsistent with due process." ${ }^{\prime 71}$ Rather than risk a guilty verdict in the Nicaraguan courts, the TNCs organized to pressure the Nicaraguan government to revoke Law 364. Dole, Dow, and Shell recruited former Clinton and Reagan administration officials to lobby the Bush administration to urge the Nicaraguan government to repeal the law. ${ }^{72}$ This strategy was evidently effective, as Secretary of State Colin Powell reportedly discussed the issue of Law 364 with Nicaragua's Foreign Minister, Norman Caldera. In March 2002, U.S. officials increased their pressure on Caldera. U.S. Ambassador Oliver Garza presented a formal letter to Caldera on March 19 "asking the new government of Enrique Bolaños... to look into the constitutionality of Law 364."73 Caldera responded by issuing a letter to the Nicaraguan Attorney General, Francisco Fiallos, noting that the critiques of Law 364 emanating from the U.S. embassy "could be valid." 74 Finally on September 2, Fiallos issued a formal petition to the Supreme Court of Nicaragua asserting that the law should be "revoked and 


\section{Ethan Grundberg}

declared unconstitutional." 75

While U.S. officials were busy pressuring Nicaragua to annul the legislation, Law 364 came under criticism during negotiations for the Central American Free Trade Agreement (CAFTA). In a round of 2002 negotiations, Mark Smith, a representative of both the Association of American Chambers of Commerce in Latin America and the U.S. Chamber of Commerce, made the argument that "the neutralization of Law 364 should take place before trade agreements are signed."76 Furthermore, the Office of the United States Trade Representative, the body charged principally with drafting and negotiating CAFTA, described Law 364 as consisting of "onerous requirements" such as "truncated judicial proceedings; imposition of a $\$ 100,000$ non-refundable bond per defendant as a condition for firms to put up a defense in court; escrow requirements of approximately $\$ 21$ million earmarked for payment of awards; irrefutable presumptions of causation; liquidated damages as minimum liabilities; and no stay of execution of a judgment pending appeal." 77

In reaction to this U.S. campaign, the former banana plantation workers resumed their direct action tactics in an attempt to ensure the preservation of Law 364. On October 20, Espinales' followers rallied in Chinandega and marched through the provincial capital "demanding that the government respect Law 364 and that their solicitations for support from the government be listened to."78 Following the local demonstration, some 1,200 former workers again marched the 133 kilometers from Chinandega to Managua with the intent of submitting a document signed by all of the plaintiffs in cases against the TNCs to the U.S. embassy, the president's home, and finally the National Assembly where they planned to remain "the time that is necessary until this issue is resolved." 79 On November 20, the protesters received promising news from the country's Supreme Court of Justice. After meeting with Espinales, the President of the Supreme Court of Justice Alba Luz Ramos and the other justices issued a statement announcing that "the opinion expressed by the Attorney General Francisco Fiallos in reference to Law 364 in no way constitutes the judgment of the Court." 80 Furthermore, the National Assembly agreed to call a special session to meet with the movement's leaders and discuss the government's position on the issue.

The National Assembly met on November 22, 2002, and issued a resolution advising the Attorney General and other government offices on the Nemagon issue. It instructed both the Human Rights Commission and Labor Issues Commission to assist the workers obtain responses to their "just demands" and recommended further studies to "evaluate the situation of those affected and their families." After the session, the President of the National Assembly commented that "the doors of the National Assembly are open not only to listen to the people affected by Nemagon, but also to tell them [the victims] that we share and are in solidarity with the pain and suffering of their families and we trust that the damages caused by the use of those chemicals will be repaid in a just manner." ${ }^{81}$ Having received the reaffirmation of the constitutionality of Law 364 from the Supreme Court and 
support from the National Assembly, the protesters returned to Chinandega to continue focusing on the legal proceedings of their law suits against the TNCs.

The victims of DBCP exposure began flooding the Nicaraguan courts with lawsuits brought against Dow, Shell, and Dole after the passage of Law 364 in early 2001. By March 24, 2001, over 400 workers had filed suit demanding a cumulative compensation of more than $\$ 400$ million from the fruit and chemical companies since the first suit was filed on February 28. Rather than filing a single class-action lawsuit, the workers and their lawyers decided to file multiple suits in groups of approximately 100 workers each because the Nicaraguan courts "would not have the ability to hear it [a class action suit]" as a result of their "limited resources," according to one of the workers' lawyers Boanerges Ojeda. ${ }^{82}$ By the end of August, 26 separate suits had been filed on behalf of over 3,600 victims of Nemagon exposure to demand a total compensation of more than $\$ 3.8$ billion. In response, the targeted TNCs had only submitted a letter denying all culpability to the workers' lawyers. ${ }^{83}$ As publicity of the lawsuits saturated Nicaragua, more former banana plantation workers organized to demand compensation from the chemical and fruit companies. In late October 2001, the Nicaraguan judicial system had received 32 separate suits for a total compensation of almost $\$ 4.5$ billion, and that number continued to grow. ${ }^{84}$ Though the workers still had not received a ruling from the Nicaraguan courts during their November 2002 demonstrations, one of their lawyers Walter Gutiérrez took the media opportunity to discuss the importance of the lawsuits. Gutiérrez noted that the suits had the potential to set an international precedent that could be used by global victims of Nemagon and other products that "have caused equal or worse disasters to the humanity of the people in poorer countries." 85

The first set of rulings on the Nemagon cases was issued on December 11, 2002, by the Third District Civil Court just weeks after the former banana plantation workers had left their protest camp in Managua with support promised by the National Assembly. The victims enjoyed another pivotal victory when the Nicaraguan court ruled in favor of 583 plaintiffs and ordered Dow, Shell, and Dole to pay a sum of $\$ 490$ million for damages caused by DBCP exposure. ${ }^{86}$ The ruling was significant for a number of reasons. First, it provided still greater media coverage of the issue, thereby acting as a recruiting agent and stimulus for greater public and governmental support. Many protesters currently demanding indemnity from the TNCs cite the ruling as their motivation for joining the movement. ${ }^{87}$ Furthermore, the ruling provided a much needed source of hope and inspiration for the thousands of workers who had been suffering from fatal illnesses and struggling for a just compensation with little success for years. One of the lawyers representing the workers commented "with this sentence we see a light in the tunnel for them." 88 More concretely, the ruling meant that the case would finally be heard in U.S. courts under the stipulations of Law 364 and with the support of the Nicaraguan government where the TNCs could no longer elude responsibility if found guilty. 


\section{Ethan Grundberg}

Once heard, the case would represent the first of its kind as a toxic damages suit filed by foreign workers against U.S.-based corporations. ${ }^{89}$

While the ruling was a huge success for the workers' movement and inspired one of the group's lawyers to proclaim "we will go to the United States to pound on the doors of the transnationals," many obstacles remained between the victims and a just compensation. ${ }^{90}$ First, the ruling only represented a decision for nine cumulative cases. By mid-December 2002, 74 more cases awaited rulings from the Third District Civil Court Judge Vida Benavente. ${ }^{91}$ Secondly, the TNCs were spurred by the verdict to revive their assault against the constitutionality of Law 364. Michael Carter, a representative of Dole Food Company, traveled to Nicaragua shortly after the ruling and told local newspapers with great confidence that the only way to resolve the issue would be an out of court settlement, since U.S. courts would not accept the cases as dictated by an unconstitutional law. ${ }^{92}$ Also, the TNCs affected by Judge Benavente's ruling almost immediately communicated their refusal to pay such a large sum to workers in the global South. After citing the fact that Hawaiian pineapple farm workers who suffered from DBCP exposure had received more than \$1 million per person, lawyer Ángel Espinoza informed the press "they [the TNCs] say that it isn't the same to pay a North American as it is to pay a Nicaraguan... They say that they will pay what is just, but they believe that what is just is $\$ 6,000$ maximum... They say that what we are asking is irrational."93

The former banana plantation workers and their lawyers could do little to respond to the criticism, and instead focused on attempting to maintain a cohesive and unified movement in the face of growing fractionalization. Of particular concern was a general assembly of Nemagon victims called by the Nicaraguan law firm Provost and Umphrey on February 9, 2003. Though it legitimately represented some former workers in cases filed against 10 different fruit and chemical corporations, the firm attempted to capitalize on the success of the main law firm representing the movement, Ojeda, Gutiérrez, Espinoza, and Associates, to attract more potential clients. Provost and Umphrey invited two U.S.-based lawyers to attend the general assembly and speak about the legal details of the case and the possibility of an out of court settlement, even though the firm had not yet received a ruling on any of the cases that they had filed. In an attempt to further associate the firm with the mutual success of Victorino Espinales' direct action tactics and the Ojeda law firm, the U.S. lawyers discussed the importance of the "marches, protests, and public demonstrations" carried out by the workers that had created a "favorable environment in the United States." 94 Lawyer Ángel Espinoza of the Ojeda firm responded to the general assembly called by the Provost and Umphrey firm by stating, "[L]acking any sense of ethics, they [Provost and Umphrey] have tried to make the people and their clients think that the ruling [of December 11] was won by them when that is not true, and in doing so have wanted to give themselves credit that isn't theirs." 95 Though the movement had never been completely unified under a single organization and several law firms represented smaller groups of victims 
of DBCP exposure, the different factions had cooperated and co-existed mostly harmoniously until late 2002.

After months of eagerly awaiting further rulings from the Third District Civil Court on the other Nemagon cases and hoping for progress in the efforts to move the case ruled upon on December 11 to the United States, Espinales and his followers began to lose patience and issued demands for the Nicaraguan judicial system to expedite the workers' cases. According to Espinales, it was imperative to quicken the legal process because "in many of the plaintiffs' cases... delay could mean death." Espinales hoped that a public demonstration on May 17, 2003, with the participation of the Nicaraguan Center for Human Rights, lawyers representing the workers, various human rights and environmental NGOs, and delegations of former banana plantation workers from Costa Rica, Honduras, and Panama who were also victims of DBCP exposure would spur the Nicaraguan courts to expedite the cases. The workers did not receive a response from the Nicaraguan judicial system despite the show of international and cross-sector solidarity.

Moreover, the illusion of unity presented in the May 2003 rally was quickly supplanted by reports of growing divisions within the movement. Seemingly due to the active campaign by the law firm Provost and Umphrey, many former banana plantation workers began to defect from the Ojeda, Gutiérrez, and Espinoza firm that had won the December 11 ruling after complaining of exorbitant monthly fees. According to thousands of protesters who gathered in Chinandega's National Stadium on August 27, 2003, to demand the payment of an indemnity from the TNCs and voice other complaints, the Ojeda firm had been charging the former banana plantation workers 67 million cordobas per month (roughly \$4 million USD) for representing the movement in court. Such fees had a devastating impact on the individual level. In the case of one campesina involved in the suit, Segunda Gómez Gutiérrez had to pay a 362,000 cordoba fee (about U.S. \$22,000) to the Ojeda law firm although she hadn't received a cent in compensation from the TNCs. ${ }^{96} \mathrm{Among}$ the other criticisms voiced at the protest was a denouncement of the movement's charismatic leader Victorino Espinales. Some 500 workers alleged that Espinales had falsified documents and forged their signatures in order to maintain their names on the list of plaintiffs represented by the Ojeda law firm. ${ }^{97}$ The accusation resulted in a government investigation. Although the investigation produced no evidence of such manipulation, the disparagement of Espinales reflected the growing disagreement within the movement over tactics and leaders.

The movement's divisions were compounded by an announcement from Dole Fruit Company in early September that the corporation refused to recognize the jurisdiction of the Nicaraguan courts. Representatives of the fruit company argued that the Nicaraguan court had failed to make a neutral ruling on the case, which jeopardized the judicial system's competency. As a result, Dole requested that the case be transferred to the United States to be heard by a neutral judge. ${ }^{98}$ Though the critique of the Nicaraguan legal system was insulting to the lawyers 


\section{Ethan Grundberg}

involved in the case, the former banana workers would finally have the opportunity to present their case in a forum from which the TNCs could not escape if found guilty.

Many of the plaintiffs involved in the suit were hopeful that a just compensation was just within reach now that the case was being transferred to the United States. However, their hopes were soon dashed by crucial translation errors that threatened to invalidate the entire case. The first error discovered by the U.S. court in the translated suit was that the defendant Dole Food Company had been misrepresented as "Dole Food Corporation." 99 Other errors were later detected in the suit, such as the inclusion of Standard Fruit and Vegetables as a defendant, a subsidiary of Standard Fruit Company that was not founded until 1998, long after the workers' exposure to DBCP. ${ }^{100}$ Days later, Judge Nora M. Manella of the Central District Court of California based in Los Angeles ruled that Dole would be dropped from the suit because of the translation error, and that a decision would be made by November 3, 2003, as to whether the case would continue or be closed. Despite the growing possibility of leaving the U.S. courts without even presenting his case, lawyer Walter Gutiérrez noted that the exclusion of Dole from the suit was of little importance. "Each one of them [the TNCs] is responsible for the total amount. In other words, one can pay the $\$ 498$ million or they can divide it between two, or divide it among three. That is their problem! But yes, they are going to have to pay." 101

Gutiérrez's remarks proved to be premature. After discovering more translation errors and "legal irregularities," in the December 11 ruling, Judge Manella closed the workers' case. In response, the law firm Ojeda, Gutiérrez, and Espinoza, which was responsible for the case filed with errors, blamed the failure on Victorino Espinales and other law firms, accusing both of being affiliated with Dole. The firm also accused Judge Manella of closing the case for political reasons, citing "a relationship between the judge, her father, and the government of President George Bush." 102 Espinales responded in typical fashion by threatening protests and direct action against the law firm in the days following the announcement and lamented that the closure of the case was "a death sentence" for the victims awaiting compensation. ${ }^{103}$

With the plaintiffs' hopes dashed and their internal conflicts becoming more pronounced, the TNCs attempted to put a final end to the workers' movement by filing a countersuit against the law firm and plaintiffs involved in the error-ridden case. Dole submitted a countersuit under the Racketeer Influenced and Corrupt Organizations (RICO) law on December 23, 2003, against the State of Nicaragua, the workers, and the law firm representing the movement in court. The U.S. federal law, which was created in 1970 to prosecute organized crime rings, was now being used by the TNCs to demand repayment for the slander suffered by the corporations involved in a fraudulent suit founded on fabricated medical evidence. The suit also alleged that in addition to not actually suffering from exposure to DBCP, many 
of the victims had never worked on the banana plantations in question. ${ }^{104}$ Shell and Dow Chemical Company followed Dole's lead and submitted similar suits on January 21, 2004, but initiated the process in civil court instead of attempting to invoke the RICO law in their case..$^{105}$

\section{To the Streets Again}

As the TNCs and the U.S. government sought to disempower the Nemagon workers' movement, Espinales and ASOTRAEXDAN responded by reaffirming the persistent power of the Nicaraguan nation-state and by harnessing nationalist opposition against foreign intervention to their struggle. Yet ASOTRAEXDAN's attempt to represent itself as an icon of Nicaraguan nationalism had great potential not only for unity but also for conflict as the movement's breed of nationalism was heavily associated with the country's most powerful anti-imperialist ideology: Sandinismo. Though the various factions of Nemagon workers in Nicaragua apparently agreed with Espinales' declaration that "Sandinismo is not just Daniel Ortega [the leader of the FLSN]," 106 they deeply disagreed about what precisely defined Sandinismo - a conflict that became especially intense after the FSLN leadership struck an infamous pact with their main rival, the ruling PLC, in August 1999. ${ }^{107}$ Nemagon victims already opposed to Espinales' leadership thus turned even more against ASOTRAEXDAN, as its charismatic leader sought not only to represent the entire Nemagon workers' movement but also to embody a new form of Sandinismo.

Espinales' turn toward a greater embrace of nationalism first became visible when he and other members of ASOTRAEXDAN planned another 12day march from Chinandega to Managua. The organizers of the march had ambitious expectations for their third trek to the capitol, estimating that at least 2,500 participants would leave from Chinandega, and at least 3,500 more would join en route as the protesters passed through Chichigalpa, León, and Managua, where 6,000 would weave through the streets. ${ }^{108}$ According to Espinales, the 6,000 participants intended to "protest in front of the National Assembly, Presidential House, and Supreme Court to demand that these state institutions assume a legal position in support of the ex-workers... and condemn what the gringo companies did to us." 109 The workers also hoped to force the government of President Enrique Bolaños to publicly oppose the RICO suit filed by Dole, which "branded them [the workers] as international gangsters." 110

The march left Chinandega on the morning of January 31 with Victorino Espinales leading the group and waving a full-sized Nicaraguan flag in an appeal to nationalist sentiment to rally popular support behind the former banana plantation workers against the foreign corporations. Espinales' tactics worked well. In a poll conducted by the conservative paper La Prensa several days after the beginning of 


\section{Ethan Grundberg}

the march, all five Managuans interviewed expressed deep support for the protesters. All five also emphasized the just nature of their struggle, including bus driver Efraín Centeno who simply argued, "We should support them because they are fighting for a just cause." 111 The marchers also won the support of key government officials, especially Sandinista politicians on the Labor and Human Rights Commissions. ${ }^{112}$ However, this support was achieved at a high cost. Three protesters died during the march and more than 600 were forced to abandon the protest and return to Chinandega due to deteriorating health. ${ }^{113}$ Still, more than 5,000 workers made it to Managua by February 11 resolved to stay as long as necessary to achieve their goals in the protest. The former banana plantation workers were no longer willing to be ignored by the Nicaraguan government. In this regard, the march represented the forced recognition of the fatal externalities of the global banana trade that had remained hidden from global consumers for decades. As Espinales noted, he wanted Bolaños to be forced to see his body and "realize that the suit that they have filed against the North American transnationals is just." 114

Once they had established themselves in the desolate field across from the National Assembly, the former banana plantation workers began to threaten more drastic measures to achieve their goals in the protest. By February 14, the workers were demanding that the government provide the victims of DBCP exposure a permanent personal pension to cover their basic subsistence costs, as well as guaranteed medical attention from the Health Ministry. ${ }^{115}$ After several days passed without a response from President Bolaños, the workers threatened more hunger strikes, crucifixions, and naked marches. Espinales expressed his desire for "the people to see that we are willing to die of hunger in front of all of the people" as a means of shaming the government to take action to avoid culpability in the starvation of the innocent workers. ${ }^{116}$ Thus, 130 men and women who had made the march to Managua initiated an indefinite hunger strike on February 17 to demand a meeting with President Bolaños. ${ }^{117}$ Espinales recognized President Bolaños previous disregard for agreements signed with the workers, but explained his fixation upon meeting with the President by questioning the competence of other governmental bodies. "We don't want anything to do with bureaucratic commissions that don't resolve anything. It has been one year since we signed an accord in which the same President Bolaños and the Attorney General of the Republic agreed to support us, but they have lied to us and they haven't complied with anything." 118

Despite their public pressure, the workers' hunger strike failed to force the government to negotiate. The strike was ended after three days when doctors advised the workers that they would need medication and food if they wanted to continue struggling for their compensations. ${ }^{119}$ Rather than accept defeat, the workers modified their tactics in hope of forcing a meeting with the President. Following a march and protest in front of the U.S. Embassy in late February, the workers

rallied in front of the Presidential House on March 5 carrying large crucifixes and repeating the threat that "we are ready to die here until we have obtained justice." 120 
The government still refused to respond.

At the same time, a long-time division in the workers' movement culminated in a massive public dispute in the capital city. Benjamín Chavez, a former journalist for the Nicaraguan newspaper El Nuevo Diario, had become the spokesperson for a group of approximately 2,000 Chinandegans led by the agricultural labor union leader Francisco Ruiz calling themselves the "legitimate victims of Nemagon." This faction of former banana plantation workers was one of several labor organization and law firms representing Nemagon victims that disapproved of Espinales' confrontational tactics and instead channeled their energy into the legal process of suing the TNCs. ${ }^{121}$ On February 24, some 500 workers in the Chávez/Ruiz camp arrived by bus in Managua to denounce Espinales and the other "imposters" camped out in front of the National Assembly. ${ }^{122}$ In addition to seeking government support, the "legitimate victims of Nemagon" seized the opportunity to further denigrate Espinales. Benjamín Chávez voiced his opinion that, "Victorino Espinales is distorting the true struggle of the banana workers, he knows that the majority of those who are there with him, in that protest, haven't even peeled a banana, but he places them there in order to take a part of the indemnity in case they win against the transnationals." The Ojeda, Gutiérrez, and Espinoza law firm also took advantage of the opportunity to criticize Espinales, adding, "The whole world says that he [Espinales] receives money from the transnationals to ruin the lawsuit." 123 In an attempt to resolve the conflict, the Office of the Ombudsman of Human Rights announced that it would provide medical examinations to both groups of workers to determine who were the real victims of agro-chemical exposure. Though the Chávez/ Ruiz group agreed to the proposal, Espinales and the members of ASOTRAEXDAN refused, noting, "the Ombudsman is not competent to determine who is ill... that is the exclusive responsibility of the courts." 124

In response to growing internal divisions in the workers' movement, the Espinales group received an upsurge of support from local individuals and organizations. Students and artists performed concerts for those camped in front of the National Assembly. Human rights and church organizations donated food, medicine, and building materials, and the renowned Mejía Godoy brothers, popular revolutionary musicians now critical of the FSLN, offered solidarity and support. Michelle Najlis, a theologian and poet who visited the protesters, later reflected that the workers "have mobilized our consciences. They figured out how to earn the respect of Nicaraguan society, not only because of the legitimacy of their demands, but also because of their exemplary attitudes and strategies. They have helped awaken civil society. Their actions should be the first steps on a new road in Nicaraguan society." 125 Espinales lamented, "It is a shame that the same sensitivity doesn't exist in the government." 126 However, more government officials had begun to pay attention to the former banana plantation workers. In response to the arrival and criticisms of the Chávez/Ruiz group, the Secretary General of the FSLN Daniel Ortega urged the workers to "unite and struggle" together against the TNCs. ${ }^{127}$ 


\section{Ethan Grundberg}

The protesters received more good news on March 2, 2004, when the Nicaraguan Judge Vida Benavente issued another ruling in favor of 81 female workers for a sum of $\$ 82.9$ million. ${ }^{128}$ According to the judge, the women suffered from uterine cancer caused by DBCP exposure while working on the plantations, as well as exposure through contaminated drinking water sources. ${ }^{129}$ The ruling was of particular significance given the traditional exclusion of women from consideration in labor struggles and the predominant machista culture that exists in Nicaragua. The March 2 ruling certainly gave hope to other female victims of Nemagon exposure who continue to face discrimination within the movement for compensation today. Indeed, many movement members consider the women's demands illegitimate, some even arguing that the women joined the struggle for lack of anything better to do. ${ }^{130}$ In response to this marginalization, a group of 50 women have organized to denounce the lawyers and movement leaders representing the victims of Nemagon exposure for refusing to represent women despite manipulating them into participating in public protests. ${ }^{131}$

As the protest outside the National Assembly continued into mid-March, more government officials voiced their support for the workers' movement. On March 16, 2004, the Ombudsman of Human Rights Benjamín Pérez requested that U.S. authorities use the same diligence to force the manufacturers and users of Nemagon to respect the human rights of those affected by the chemical that the government uses to force nation-states to respect citizens' human rights. ${ }^{132}$ The same day, the popular Sandinista mayor of Managua Herty Lewites visited the protest camp and promised to pressure President Bolaños to take action on the issue. The mayor added that in addition to support from the municipal government, "I believe that it is also the responsibility of the national government to see this problem."133

Finally after 40 days camped in front of the National Assembly and after repeated threats of starvation, live burials, naked marches, and crucifixion, President Bolaños conceded to increasing pressure and met with the protesters. After a day of negotiation, Bolaños, Espinales, Benjamín Chávez, as well as other government officials and movement leaders signed the El Raizón Accords on March 20, 2004. ${ }^{134}$ The agreement consisted of five points that established an outline for action by both the government and the workers' movement. The first point mandated that the divided movement must unite their efforts and create a single petition of demands for the government's own use and to present to the TNCs. Secondly, the government agreed to provide legal assistance to the victims and provide the movement with lawyers based in Washington to assist in their U.S. law suits. Third, Bolaños agreed to send the Ombudsman of Human Rights Benjamín Pérez to the U.N. International Human Rights Convention in Geneva, Switzerland with two movement representatives to present their case. Fourth, the government agreed to protect Law 364 from revision. ${ }^{135}$ Finally, the protesters agreed to end their protest in front of the National Assembly in exchange for government-provided transportation back to Chinandega and promises of medical attention. Espinales 
expressed cautious optimism after the accords were signed, stating "[F]or now, we will leave satisfied, but we will continue in the struggle." 136 As the thousands of former banana plantation workers boarded buses to return home, one protester observed, "I only hope that I don't have to come back to Managua to protest, it is hard for an old woman to sleep on the ground."'137

Just days after the agreement had been signed and the protesters had returned to Chinandega, the El Raizón Accords came under criticism from human rights organizations and began to crumble. On March 26, Benjamín Pérez announced that he would not comply with Bolaños' request to attend the UN meeting in Geneva to present the Nemagon issue. The Ombudsman defended his decision by noting the short notice provided by Bolaños and adding, "I can't travel in an improvised manner to an event of such magnitude." 138 In light of this failure to abide by the El Raizón Accords, the legal advisor for the Nicaraguan Center for Human Rights Bayardo Izabá argued, "We think that the president lied to those affected by Nemagon exposure. He is a liar or an irresponsible person," in addition to asserting that Bolaños had hastily signed the agreement to rid Managua of the protesters in preparation for an upcoming governmental summit. ${ }^{139}$

Despite the initial failures of the El Raizón Accords, the workers' hopes for a just compensation from the TNCs were rekindled when another suit was filed in the Los Angeles courts in mid-April. Juan José Dominguez, a personal injury attorney based in Los Angeles, filed the suit against the TNCs alleging that the corporations produced and used toxic substances while intentionally withholding information about their risks from the workers. The suit was filed on behalf of 25 individual plaintiffs, though the lawyer represented more than 10,000 victims of Nemagon exposure at the time. With the support provided by Law 364, Dominguez confidently stated, "Now there is no escape for the multinationals. The defendants will have to choose the country that pleases them to fight this case." Dominguez continued, "We invite them [the TNCs] to fight in Los Angeles if they think that the system here in Nicaragua is corrupt." 140 The Los Angeles courts formally accepted the case on April 20, 2004, re-opening not only the possibility for compensation of the Nicaraguan workers, but a new era of international corporate accountability. Dominguez noted, "This case can set a legal precedent and be an example for all nations, that the multinational corporations can be held responsible for illicit actions that result in injuries, damages, or exploitation of citizens."

The former banana plantation workers continued their attempts to recruit more victims of DBCP exposure into their movement as they pursued legal action in the United States. Branching out beyond the banana plantations of Chinandega, the movement expanded into tobacco and sugar cane growing regions of the northern state of Estelí. Although the sugar and tobacco plantations were either state-owned or domestically managed, workers in the regions assert that the plantations had used pesticides derived from DBCP, produced by the TNCs Shell and Dow, and that they now suffer the negative health effects of exposure. ${ }^{142}$ In addition to exposure 


\section{Ethan Grundberg}

on the tobacco and sugar cane plantations, many workers in Estelí migrated west to Chinandega after the annual coffee harvest to seek seasonal employment on banana plantations. Thus, the National Association of People Affected by Poison officially opened an office in Estelí in early July 2004, representing an estimated 700 victims of DBCP exposure. ${ }^{143}$

\section{The March of No Return}

While the government had provided some institutional support for their movement, the workers understood that they would have to continue to pressure the National Assembly and President to comply with their promises. However, they were unable to use traditional sources of influence and power to interact with the state. Instead, Espinales and the other members of ASOTRAEXDAN repeatedly used the threat of creating a public spectacle at the expense of their own bodies to simultaneously shame the government, create public outrage and support, and reaffirm their status as victims of violence entitled to justice. This tactic follows an emerging trend of historically marginalized communities in Latin America using public performance as "a form of political action based on visual display, undertaken by specifically positioned social groups and actors attempting to stamp society with their own agenda."144

Much of the workers' ire resulted from the Nicaraguan government's refusal to implement an effective medical assistance program for those affected by DBCP exposure. By September 2004, the workers were running out of patience and began to seek the assistance of the Nicaraguan Center for Human Rights (CENIDH) to pressure the government to comply with the El Raizón Accords. In response, CENIDH made several phone calls to officials in the Ministry of Health, and considered rallying international solidarity if no changes were made. CENIDH's legal advisor Bayardo Izabá threatened, "If a positive response does not exist, CENIDH will see it necessary to begin an international petition to denounce the attitude of the government, that it has put the health and lives of millions of people affected by the pesticide in danger."145

Despite these threats, the promised governmental medical attention never came to fruition. The Ministry of Health explained that the failure to attend to the needs of the Nemagon victims was a result of a chronic lack of resources. "The doctors declare themselves bankrupt because of the lack of materials." ${ }^{146}$ The workers were reluctant to accept the excuse of the practical impossibility of establishing an effective health care program and redirected their dissatisfaction again at the National Assembly in hopes of increasing funding for the Ministry. "The members of parliament told us that they would support our demand, we hope they will now support us because the lack of medicine has killed many of us campesinos," noted Espinales. ${ }^{147}$ The workers added further pressure on the government by threatening to return to Managua in January if their demand to increase allocated funds for the 
Ministry of Health by 100 million cordobas (approximately $\$ 6.2$ million USD) in the 2005 operating budget. ${ }^{148}$

After another month of governmental inaction, Espinales and the members of ASOTRAEXDAN decided that they had no other option but to return to Managua to protest in front of the National Assembly for the fourth time since 1999. In explaining the decision, Espinales ranted, "They [the government] have promised us everything, they have signed agreements upon agreements with us, they have told us that they are going to help us, they have formed commissions upon commissions, but later no one complies, they run from us to their offices, they don't meet with us and only when we protest do they return our calls... now we want real justice." ${ }^{149}$ While Espinales' sentiments were widely shared among the former banana plantation workers, the 4,200 members of the Chávez/Ruiz faction refused to participate in the planned march. Chávez explained the decision by arguing that he and the law firm representing his faction (Ojeda, Gutiérrez, and Espinoza) had good relations with the Ministry of Health and suggested that it would be inhumane to force the ill to walk 133 kilometers to Managua. Nonetheless, Espinales continued planning the march and sought solidarity from other sectors, such as the newly mobilized sugar cane workers in Estelí, landless campesinos movements, and other human rights activists. ${ }^{150}$ Espinales estimated that 8-10,000 people would leave Chinandega on the morning of February 20, 2005, in a massive display of discontent with the government's handling of the Nemagon issue. The protesters, who would walk 12 kilometers per day to reach Managua in early March, expressed three principal demands before their departure. First, they reiterated their demand for a 100 million cordoba allocation for medical attention in the 2005 government operating budget. Second, they demanded the provision of an economic pension to the former workers to cover basic living expenses. Finally, they insisted upon a revision of the February 2004 El Raizón Accords, which had been largely ignored by the government. ${ }^{151}$

Approximately 3,000 protesters left as planned on the morning of February 20 with Espinales again leading the march carrying the Nicaraguan flag on his shoulder. After the march had begun, Espinales announced the workers' intentions to remain in Managua until a new agreement was not just signed, but fulfilled by the government. "This is a march of no return, because we are going to demand not just the signing of agreements like we did in El Raizón in 2004, but also compliance with those agreements." 152

The first to respond to the massive protest was not the Nicaraguan government, but rather the TNCs targeted by the movement. Just days after the protesters settled in front of the National Assembly in Managua, Dole Food Company spokesperson Humberto Hurtado began issuing statements criticizing Law 364 and discrediting the movement. Hurtado asserted, "There is nothing to discuss, unless they [the workers] withdraw their lawsuits and abandon Law 364." "153 The next day, Hurtado dismissed the claims that DBCP exposure was responsible for the array of illnesses 


\section{Ethan Grundberg}

the former banana plantation workers suffer. "According to trustworthy scientific evidence, DBCP, known as Nemagon, only produced a decrease in sperm in the men who worked in the factories that produced the chemical." 154 He continued, "There is no reliable scientific evidence that links Nemagon with all of the other illnesses in the people who applied this product." 155 Dole's arguments did not convince the more than 12,000 workers involved in lawsuits against the TNCs, and only elicited more fiery words from movement leader Victorino Espinales, who called them "idiotic and ridiculous." 156

The first signs of a governmental response to the new protest came from political parties rather than the government. On March 5, the leftist Sandinista Party (FSLN) passed a party resolution in favor of supporting the protesters and attempting to obtain government support for their demands. Various members of the center-right Liberal Constitutionalist Party (PLC) also expressed formal support for the workers and pledged to fight for government action. However, the workers were distrustful of the promised support after years of experiencing institutional deceit. "We do not want to be the political flag of anyone, of any party," stated Espinales. He continued, "Until now we have navigated with the blue and white of the country, and as an organization...we are apolitical, and as a result we distrust the burst of politicians beginning to offer help who never give it concretely." 157 This contempt for the PLC and the FSLN echoed popular disillusionment with national politics in the country in post-Pacto Nicaragua.

However, the Bolaños government still refused to react to the Nemagon protest. As a result, both the workers and other organizations began to increase pressure on the president to resolve the conflict. In mid-March, the new Human Rights Ombudsman Omar Cabezas, a popular former revolutionary leader, denounced the Nicaraguan state and the targeted TNCs in front of the InterAmerican Court of Human Rights, an institution of the Organization of American States based in Costa Rica, for violating the human rights of those affected by DBCP exposure. ${ }^{158}$ In addition to Cabezas' official denouncement, the workers issued a threat for violent action after the government announced that it was not planning to address the Nemagon issue before leaving for a weeklong vacation during Holy Week. Espinales announced the formation of what he called the "sacrifice brigade" on March 8. "There will be 90 men. 30 will bury themselves alive, 30 will crucify themselves, and another 30 will begin a hunger strike. If they [the government] remember us some day, they will find a cemetery here." ${ }^{159}$ Moreover, the workers threatened self-immolation if the government refused to provide the money for medical attention promised in the El Raizón Accords. Sixty-five-year-old Ramón Catalino Suazo Molina, one of the protesters, explained the seemingly extreme tactics by observing, "Desperation can make you obligated to do anything." 160

As Holy Week approached, the government had still refused to meet with representatives from the movement or take action on the issue. In response, Espinales and ASOTRAEXDAN issued a new set of demands and threatened self- 
immolation if the government refused to discuss the list in the next 24 hours. First, the workers demanded the immediate ban of a group of 12 agro-chemicals still used in Nicaragua known as the "dirty dozen," such as Aldicarb and other highly toxic chemicals that have been linked to negative health effects. Second, housing and land for more than 3,000 Chinandegans were requested from the government. Finally, the workers reiterated their demand for a government-sponsored pension to cover the cost of living. ${ }^{161}$ After releasing the demands, Espinales warned, "if they [the members of parliament] leave for vacation today, we are going to begin to execute our plans." 162

Though Espinales was the target of harsh criticism from CENIDH, lawyer Walter Gutiérrez, and Benjamín Chávez for "forcing them [the workers] to make risky decisions, like the sham of crucifixion, burials, and immolations," the pressure was effective. ${ }^{163}$ The workers were able to pressure the government to agree to implement the El Raizón Accords and begin a census of those affected by Nemagon. Bolaños also agreed to obtain 80 visas for workers and movement leaders to travel to the U.S. to provide legal testimonies and continue the judicial process. ${ }^{164}$ Unlike previous agreements that pacified the protesters but were never implemented, the workers immediately began to enjoy the benefits of the new agreement signed on March 18. Within days, the Ministry of Health had devoted 75 employees to opening five health centers in Managua exclusively for treating and testing the victims of DBCP exposure. ${ }^{165}$ Though children of the former banana plantation workers were not granted access to the centers despite allegations that they suffered genetic illnesses related to the agro-chemical, the Ministry of Health's actions represented a huge victory for the protesters. ${ }^{166}$

The workers had little time to celebrate their achievement before receiving surprising news of secret negotiations between Dole Food Company and the Nicaraguan government to resolve the Nemagon issue out of court without consulting the victims. In late March, the BBC published a report in which Dole's Executive Vice President Michael Carter confessed to having negotiated with the Nicaraguan Attorney General Alberto Novoa to arrange a settlement. Dole proposed that the Nicaraguan government permit the fruit corporation to return to Nicaragua, increase direct foreign investment, and create thousands of jobs in the impoverished country. In exchange, the Nicaraguan government would abolish Law 364, eliminating the legislative support that had allowed the workers to circumvent forum non conveniens and file suit in the United States. ${ }^{167}$ Such action would almost certainly ensure the failure of the thousands of lawsuits against the TNCs representing a sum of almost $\$ 17$ billion. Though the government denied negotiating with Dole, the allegations infuriated the workers' movement. Espinales responded to the news by exclaiming, "We do not accept that while the government publicly promises to help us, they are talking under the table with the transnationals to throw out our lawsuits. That would be treason..."168 The government has steadfastly denied the charges.

Already enraged by the allegations of secret negotiations between Dole and 


\section{Ethan Grundberg}

the government, the workers sought to force Human Rights Ombudsman Omar Cabezas to fulfill his promise to represent the protesters' interests in the government. On the afternoon of April 7, a large group of workers marched to the office of Cabezas to demand an immediate meeting with him. Although Cabezas agreed to meet with Espinales and other representatives, the accompanying workers occupied the building to further pressure Cabezas to comply with their demands. After three hours of negotiations, the workers left peacefully having reached an agreement with Cabezas that included continuing to hold the government accountable for the March 18 agreement and presenting the Nemagon issue to the $61^{\text {st }}$ Session of the United Nations Human Rights Commission on April 11, 2005, in Geneva. ${ }^{169}$

The following week, the protesters initiated another direct action campaign targeting the members of the National Assembly for refusing to meet with the workers. On April 14, a group of 30 began an indefinite hunger strike. Espinales communicated the group's intentions of blocking the streets, expanding the hunger strike, and beginning self-immolations if the police intervened and members of parliament continued to refuse to meet with them. ${ }^{170}$ These more conventional movement tactics were augmented by attempts to secure greater local and international support to pressure the government to reach an agreement with the protesters. Local human rights groups and religious organizations began to provide the protest camp with food donations and even agreed to establish a solidarity camp beginning May 1 . Deborah García, a representative of one of the religious organizations involved in the solidarity camp, explained their actions by arguing, "Because of the suffering of all of them, we are trying to make them [the government] listen and not forget these companions." 171 Movement leaders even tried to contact the leftist documentary filmmaker Michael Moore to raise international consciousness of their struggle. ${ }^{172}$

In the face of mounting pressure, the Nicaraguan government finally reached a comprehensive agreement with the protesters on May 13. The 19point agreement was signed both by government officials, representatives of the Nemagon victims' movement, affected sugar cane workers, and members of the landless campesinos movement after the protesters had spent 73 days marching and camping in front of the National Assembly. Among the provisions of the agreement, the affected banana and sugar cane workers were granted 80 visas to travel to the U.S. to provide testimony in their lawsuits, lifetime health care, inclusion of some 17,000 former workers into existing social security and state pension programs, acceptance into the government-sponsored program Pound for Pound to provide basic foodstuffs, the establishment of environmental impact studies in communities potentially contaminated with agro-chemicals, the development of housing projects for landless and homeless movement members, and the provision of 300 coffins per year to bury those passing away from Nemagon-related illness. In exchange, the protesters were provided with free transportation back to their homes in Chinandega and Estelí. However, 300 protesters elected to stay behind to ensure that the newly signed agreement was enacted and to further pressure government officials who had 
communicated with the lawyers representing the TNCs. ${ }^{173}$ Unlike the previous E1 Raizón Accords of 2004, with which the government failed to comply, the May 13 agreement received formal institutional support from several international human rights organizations, such as CENIDH and the International Federation of Human Rights. Julio César Cruz, a former banana worker on the El Relámpago plantation, explained that he was pleased that such organizations were involved "because in this way they protect the struggle at the international level."174

The May 13 agreement represented a huge victory for the victims of Nemagon exposure and initiated a deluge of progress in the movement. The first workers arrived in the United States in late July to begin providing witness statements to be used in the U.S. lawsuits against Dole, Dow, and Shell. ${ }^{175}$ Weeks later, the workers received news of another judicial victory in Nicaragua. Chinandegan Judge Socorro Toruño ruled in favor of 150 former banana workers in early August for damages resulting from DBCP exposure for a sum of $\$ 97$ million. ${ }^{176}$ By the end of the month, the more than 15,000 workers involved in lawsuits against the fruit and chemical corporations were informed that the Ninth Circuit U.S. Federal Court of Appeals had issued a ruling in support of the initial December 11, 2002, Nicaraguan verdict in favor of 464 workers for $\$ 489.4$ million. Though the ruling has been appealed and is still in court, Walter Gutiérrez assured workers that, "We are struggling to bring justice to our Nicaraguan brothers and so we will continue on until we have won all of the lawsuits in Nicaragua, and although the companies run from us, we will follow them to China or Africa if it is possible." 177 Finally, the National Assembly reaffirmed its support for the Nemagon victims in mid-September by passing a resolution re-asserting the constitutionality of Law $364 .{ }^{178}$ Satisfied with the successful implementation of the promised programs and the renewed support for Law 364, the remaining several hundred protesters camped in front of the National Assembly decided to return home on October 9, 2005. ${ }^{179}$

However, the workers' struggle for a just compensation from the TNCs remains riddled with obstacles. In addition to having to overcome the improbability of winning a lawsuit against the massive TNCs that have promised "a vigorous defense" in court, the movement continues to struggle with crippling internal divisions. ${ }^{180}$ Since the negotiation of the May 13 agreement, Espinales has been criticized for everything from withholding the passports intended for plaintiffs testifying in the U.S. suits to stealing a 1995 Isuzu Rodeo, which he claims was given to him by U.S. lawyer Juan José Domínguez. ${ }^{181}$ Movement leaders made progress towards unification in late October by consolidating eight separate factions representing a total of 23,333 former workers under the leadership of various law firms, the Rural Workers Association (ATC), and other labor organizations. However, Espinales' organization ASOTRAEXDAN was excluded from the unified body and accused of fraudulently attempting to represent the entirety of the Nemagon victims' movement. ${ }^{182}$ Espinales has also been working with the Latin American Regional Union of Food, Agricultural, Hotel, Restaurant, Tobacco, and 


\section{Ethan Grundberg}

Allied Workers Association (Rel-Uita, based in Montevideo, Uruguay) to found a new workers' center scheduled to open in February 2006 to coordinate multisector labor movements in Nicaragua and continue organizing victims of DBCP exposure. ${ }^{183}$

\section{Conclusion}

Although Dow and Shell were aware of the health risks posed by the nematicide as early as 1954, the Nicaraguan banana workers suffering from exposure to DBCP are still waging a battle for a just compensation from the TNCs. Their struggle has led them from the courtrooms of Nicaragua, to the streets of Managua, and finally to the U.S. in hopes of finding justice. Though internal divisions, legal expenses, and the enormous power of the TNCs threaten to undermine the workers' hopes for victory, the Nicaraguan movement has rekindled a global movement for compensation from Dole, Dow, and Shell. Lawsuits against the fruit and chemical corporations have been filed in Ecuador, Venezuela, ${ }^{184}$ and Colombia ${ }^{185}$ for damages resulting from exposure to $\mathrm{DBCP}$, and popular movements have re-emerged in Costa Rica demanding medical attention and compensation. ${ }^{186}$ The Nicaraguan workers now comprise just one of several independent national movements in Latin America fighting the same transnational targets.

The success of the Nicaraguan movement in rallying behind a mix of popular nationalism and Sandinismo to pressure the government into action illustrates a viable alternative to popular conceptualizations of "globalization from below." Rather than transnationalizing their struggle, the Nicaraguan workers effectively used the power of the spectacle to construct a highly visible and patriotic mobilization with popular resonance. In order to avoid losing even greater legitimacy in this age of small government and market supremacy, the National Assembly and President Bolaños were forced to support the movement and challenge the global agents of neo-liberalism. The movement's success indicates that perhaps the nationstate should still be considered a viable actor despite the confines of increasing transnationalism in the age of globalization.

Although the workers have returned home to Chinandega for the time being, their battle against the TNCs is far from over. None of the protesters seemed eager to return to Managua, but they all seemed ready to continue struggling until their death if necessary. As the protesters camped in front of the National Assembly have chanted many times over the years, "la lucha sigue"- the struggle continues.

I would like to thank Gustavo Pérez Zamora for his endless insight and generosity, Marlon Villereyna Acuña for his encouragement, inspiration, and friendship, Professors Laura Gotkowitz and Rudi Colloredo-Mansfeld for their thoughtful comments, and Professor Michel Gobat, whose passion for Nicaraguan history and incredible patience made this piece possible. 


\section{Confronting the Perils of Globalization}

\section{Endnotes}

1 Imre Szeman, "Globalization," in John Hawley, ed., Encyclopedia of Postcolonial Studies (Westport, CT: Greenwood Press, 2001), 209.

2 Douglas Kellner, “Theorizing Globalization," Sociological Theory 20, no. 3 (November 2002): 302.

3 William I. Robinson, Transnational Conflicts: Central America, Social Change, and Globalization (New York: Verso, 2003), 324.

4 Michael Hardt and Antonio Negri, Empire (Cambridge, MA: Harvard University Press, 2000), 400 .

5 Jeremy Brecher, Globalization from Below: The Power of Solidarity (Cambridge, MA: South End Press, 2000).

6 Robinson, Transnational Conflicts, 46.

7 See Fernando Coronil and Julie Skurski, "Dismembering and Remembering the Nation: The Semantics of Political Violence in Venezuela," Comparative Studies in Society and History 33, no. 2 (April 1991): 288-337, for a discussion of constructions of national historical narratives.

8 Jeffrey M. Paige, Coffee and Power: Revolution and the Rise of Democracy in Central America (Cambridge, MA: Harvard University Press, 1997), especially chapters 5 and 9.

9 David M. Goldstein, The Spectacular City: Violence and Performance in Urban Bolivia (Durham, NC: Duke University Press, 2004), 17.

10 Marc Edelman, Peasants Against Globalization: Rural Social Movements in Costa Rica (Stanford, CA: Stanford University Press, 1999), 187.

11 Thomas F. O'Brien, The Revolutionary Mission: American Enterprise in Latin America, 19001945 (New York: Cambridge University Press, 1996), 59-70.

12 Alvaro Martinez Cuenca, Banana Libre (Managua, Nicaragua: Nueva Nicaragua, 1991), 34.

13 Thomas L. Karnes, Tropical Enterprise: The Standard Fruit and Steamship Company in Latin America (Baton Rouge, LA: Louisiana State University Press, 1978), 142.

14 Cuenca, Banana Libre, 35, 134-36.

15 Ibid., 41-115.

16 Lori Ann Thrupp, "Pesticides and Policies: Approaches to Pest-Control Dilemmas in Nicaragua," Latin American Perspectives 15, no. 4 (Fall 1988): 41.

17 Virginia Scott Jenkins, Bananas: An American History (Washington, D.C.: Smithsonian Institution Press, 2000), 32-34.

18 Lori Ann Thrupp, "Sterilization of Workers from Pesticide Exposure: The Causes and Consequences of DBCP-Induced Damage in Costa Rica and Beyond," International Journal of Health Services 21, no.4 (1991): 738-40.

19 Ibid.

20 Cathy Trost, Elements of Risk: The Chemical Industry and its Threat to America (New York: Times Books, 1984), 37.

21 Ibid., 45-8.

22 Office of Environmental Health Hazard Assessment, "Public Health Goal for 1,2-Dibromo-3chorlopropane (DBCP) In Drinking Water," California Environmental Protection Agency, February 1999: 2.

23 José Adán Silva, "Víctimas del Nemagón: Génesis de una pesadilla," La Prensa, 10 November 2003.

24 Thrupp 1991, 744.

25 Thrupp 1991, 738-39; Raquel Fernández, "Banana Workers Put Shell on Trial," Revista Envio, no. 165 April 1995.

26 Ibid.

27 Personal interviews with nemagon victims, May 2005.

28 Thrupp 1991, 739.

29 José Adán Siva, “El Valle de los condenados,” La Prensa, 11 November 2003.

Iowa Historical Review 


\section{Ethan Grundberg}

30 Lizabeth García, “Inspeccionan barriles de Nemagón,” El Nuevo Diario, 12 November 2002.

31 Office of Environmental Health Hazard Assessment, "Public Health Goal for 1,2-Dibromo-3chorlopropane (DBCP) In Drinking Water,” California Environmental Protection Agency, February 1999: 9-13.

32 Sasha Lilley, "Barren Justice," Corpwatch. 13 May 2004.

33 Thrupp "Sterilization of Workers from Pesticide Exposure,", 746.

34 José Adán Silva, "Víctimas del Nemagón: Génesis de una pesadilla," La Prensa, 10 November 2003.

35 Mario Sánchez P., "Peligra vida de bananeros," La Prensa, 4 September 2000.

36 Victorino Espinales Reyes, quoted in "Afectados por pesticidas siguen pidiendo justicia," El Nuevo Diario, 10 September 2000.

37 Benjamín Chávez and Félix Thomas, "Afectados por Nemagón llegan hoy a Asamblea," El Nuevo Diario, 15 February 2000.

38 "Don Victorino, artifice de la batalla legal," La Prensa, 9 September 2001.

39 "El Otro Infierno: La Maraña de Intereses en el Caso Nemagón," La Prensa, 13 November 2003.

40 Thrupp, "Sterilization of Workers from Pesticide Exposure," 734.

41 Ibid., 735-36.

42 Michael Satchell, “A Vicious 'Circle of Poison'," U.S. News and World Report, 10 June 1991, 32.

43 Thrupp, "Sterilization of Workers from Pesticide Exposure," 736.

44 Ellen Hosmer, "The South's Day in Court," Multinational Monitor. July/August 1990

45 Sasha Lilley, "Barren Justice," CorpWatch, <http://www.corpwatch.org/article. php?id=11330>.

46 "The Price of Bananas," The Economist, 12 March 1994, 48.

47 "Banana Workers Win Against Dow, Shell \& Standard Fruit," Pesticide Action Network Updates Service, 6 January 2003; David Gonzalez, "Banana Workers Get Day in Court," New York Times, 18 January 2003.

48 "Victims of Nemagon Hit the Road," Revista Envio, June 2005, no. 287.

49 José Adán Silva, "El valle de los condenados," La Prensa, 11 November 2003.

50 Benjamín Chávez and Félix Thomas, "Afectados por Nemagón llegan hoy a Asamblea," El Nuevo Diario, 15 February 2000.

51 Ellen Hosmer, “The South's Day in Court,” Multinational Monitor, July/August 1990.

52 “Capitol Research Reports: Forum Non Conveniens (1997 Amendment)," Capitol Research Services of Texas.

53 Iván Castro, “Afectados por pesticidas siguen pidiendo justicia,” El Nuevo Diario, 10 September 2000.

54 José Adán Silva, “El valle de los condenados," La Prensa, 11 November 2003.

55 Benjamín Chávez and Félix Thomas, "Preso ex diputado Victorino Espinales," El Nuevo Diario, 18 March 1999.

56 Ibid.

57 Moises Castillo Zeas, "Viacrucis bananero," El Nuevo Diario, 24 November 1999.

58 "Victims of Nemagon Hit the Road," Revista Envio, June 2005, no. 287.

59 Moises Castillo Zeas, "Viacrucis bananero," El Nuevo Diario, 24 November 1999.

60 "Victims of Nemagon Hit the Road."

61 Moises Castillo Zeas, "Viacrucis bananero," El Nuevo Diario, 24 November 1999.

62 Benjamín Chávez and Félix Thomas, "Conomción social en Chinandega," El Nuevo Diario, 17 July 2000.

63 Mario Sánchez P., "Peligra vida de bananeros," La Prensa, 4 September 2000.

64 Edgard Barberena S., "'Marcharemos desnudos'," El Nuevo Diario, 6 September 2000.

65 Humberto Meza, “Afectados por Nemagón emplazan al Parlamento,” La Prensa, 6 September 


\section{Confronting the Perils of Globalization}

2000.

66 The National Assembly approved the legislation on November 23, but it did not become law until receiving approval from the executive branch in January 2001.

67 Sasha Lilley, "Barren Justice," CorpWatch, <http://www.corpwatch.org/article. php?id=11330>.

68 Maria Haydee Brenes Flores, “Maracharán víctimas del Nemagón,” El Nuevo Diario, 15 October 2002.

69 Ary Neil Pantoja, "Excluyen a transnacionales en demanda del Nemagón," La Prensa, 31 October 2003.

70 Lilley, "Barren Justice."

71 Ibid.

72 David Gonzalez, "Banana Workers Get Day in Court,” New York Times, 18 January 2003.

73 Lilley, "Barren Justice."

74 Victorino Espinales and Vicente Boix, "Imperialismo y lamebotismo," El Nuevo Diario, 27 October 2002.

75 Octavio Enríquez, “Marcha del Nemagón,” El Nuevo Diario, 14 October 2002.

76 Lilley, "Barren Justice."

772003 Nicaragua Trade Summary, Office of the United States Trade Representative, <http:// www.ustr.gov/assets/Document_Library/Reports_Publications/2003/2003_NTE_Report/asset_ upload_file325_6212.pdf?ht=law\%20364\%20nicaragua\%20law\%20364\%20nicaragua>.

78 Maria Haydee Brenes Flores, "Maracharán víctimas del Nemagón,” El Nuevo Diario, 15 October 2002.

79 Ramón Cruz Dolmus, “Avanza a Managua marcha de víctimas del Nemagón,” El Nuevo Diario, 16 November 2002.

80 Maria Haydee Brenes Flores, "Logran apoyo marchistas del Nemagón," El Nuevo Diario, 21 November 2002.

81 Edgard Barberena and Sergio Aguirre, "Respaldo legislativo a víctimas de Nemagón," El Nuevo Diario, 23 November 2002.

82 Lizbeth García, "Completan demanda por daños del Nemagón," El Nuevo Diario, 24 March 2001.

83 Janelys Carillo Barrios, "Nemagón: Verdugo de generaciones," La Prensa, 9 September 2001.

84 Janelys Carillo Barrios, "Demandan justicia desde la tumba," La Prensa, 20 October 2001.

85 Maria Haydee Brenes Flores, "Maracharán víctimas del Nemagón," El Nuevo Diario, 15 October 2002.

86 Roberto Collado Navarez, "Víctimas de Nemagón ganan gran demanda," El Nuevo Diario, 14 December 2002.

87 Personal interviews with protesters, April-May 2005

88 Roberto Collado Navarez, "Víctimas de Nemagón ganan gran demanda," El Nuevo Diario, 14 December 2002.

89 Ibid.

90 Mirna Velásquez Sevilla, “Lucha del Nemagón se trasladará a EE.UU.," La Prensa, 17 December 2002.

91 Ibid.

92 Luis Galeano and Ramon Cruz Dolmus, "Dole presiona a los afectados de Nemagón," El Nuevo Diario, 20 January 2003.

93 Mirna Velásquez Sevilla, "Transnacionales no quieren pagar a víctimas de Nemagón," La Prensa, 3 February 2003.

94 Carol Munguía, “Claman unidad de afectados del Nemagón,” La Prensa, 11 February 2003.

95 Mirna Velásquez Sevilla, "Denuncian engaño contra víctimas del Nemagón," La Prensa, 12 February 2003.

96 José Adán Silva and Carol Munguía, "Negocio Redondo con víctimas de Nemagón," La Prensa, 


\section{Ethan Grundberg}

28 August 2003.

97 Ibid.; Mirna Velásquez Sevilla, "Se disputan futura indemnización," La Prensa, 26 February 2003.

98 Carol Munguía, "Desconocen competencia nica en casos Nemagón,” La Prensa, 4 September 2003

99 José Adán Silva, "Peligra juicio Nemagón,” La Prensa, 21 October 2003.

100 Lucía Navas, “Apelar decision de jueza sería errado,” El Nuevo Diario, 28 Octuber 2003.

101 José Adán Silva, "Plazo fatal a juicio del Nemagón,” La Prensa, 24 October 2003.

102 José Adán Silva and Luis Alemán, "Viene contraataque en caso Nemagón," La Prensa, 27 October 2003.

103 José Adán Silva, “Adiós millones del Nemagón,” La Prensa, 25 October 2003.

104 José Adán Silva, Acusan de 'capos' a víctimas de Nemagón,” La Presna, 29 January 2004

105 José Adán Silva and Carol Munguía, "Más demandas contra víctimas de Nemagón," La Prensa, 30 January 2004.

106 Carlos Amorín, "Los damnificados negocian directamente con las empresas," <http://www. rel-uita.org/agricultura/agrotoxicos/nemagon/con_victorino_espinales.htm> (18 October 2005).

107 Marc Cooper, “The Lost Revolution,” Mother Jones, September/October 2001.

108 Ibid.

109 José Adán Silva, “Hoy marcha del Nemagón,” La Prensa, 31 January 2004.

110 Moisés González Silva, "Víctimas del Nemagón regresaron a Managua," El Nuevo Diario, 11 February 2004.

111 Aura Lacayo Matus, “¿y usted qué opina?: Sobre nueva marcha de los afectados por el Nemagón," La Prensa, 5 February 2004.

112 José Adán Silva, "Marcha del Nemagón frente a la Asamblea Nacional," La Prensa, 11 February 2004.

113 Moisés González Silva, "Víctimas del Nemagón regresaron a Managua," El Nuevo Diario, 11 February 2004; José Adán Silva and Consuelo Sandoval, "Fallece caminante de march del Nemagón," La Prensa, 13 February 2004.

114 Haydée Brenes F., "Sigue calvario de víctimas de Nemagón," El Nuevo Diario, 17 February 2004.

115 Octavio Enríquez, "Nemagón los mata y abandono los remata," El Nuevo Diario, 14 February 2004.

116 José Adán Silva, "Subirá tono de protesta de ex bananeros," La Prensa, 17 February 2004.

117 José Adán Silva, "Masiva huelga de hambre en protesta del Nemagón," La Prensa, 18 February 2004.

118 José Adán Silva, “Ex bananeros exigen reunión con Bolaños,” La Prensa, 19 February 2004.

119 José Adán Silva, "Paran huelga de hambre en protesta del Nemagón," La Prensa, 21 February 2004.

120 "Vía cruces de victimas del Nemagón,” El Nuevo Diario, 6 March 2004.

121 José Adán Silva, "Pleito entre bananeros," La Prensa, 24 February 2004.

122 José Adán Silva, "Protesta del Nemagón dividida en dos bandos," La Prensa, 25 February 2004.

123 José Adán Silva, "Pleito entre bananeros," La Prensa, 24 February 2004.

124 José Adán Silva, "PDDH dirá quiénes son víctimas del Nemagón," La Prensa, 26 February 2004.

125 "Victims of Nemagon Hit the Road." Revista Envio. June 2005, no. 287.

126 José Adán Silva, “Crece solidaridad con víctimas del Nemagón,” La Prensa, 1 March 2004.

127 Ibid.

128 Mirna Velásquez Sevilla, "Víctimas del Nemagón ganan otra demanda," La Prensa, 3 March 2004.

129 Eloisa Ibarra, "US\$ 82 millones para 81 mujeres,” El Nuevo Diario, 4 March 2004. 


\section{Confronting the Perils of Globalization}

130 Personal conversations with protesters, May 2005.

131 José Adán Silva, "Denuncian gran discriminación," La Prensa, 29 July 2005.

132 Elízabeth Romero, "Exigen reciprocidad de EE.UU. con las víctimas del Nemagón," La Prensa, 17 March 2004.

133 Roberto Pérez Solís, "Lewites mediará por afectados del Nemagón," La Prensa, 17 March 2004.

134 Joaquín Tórrez A., "Ex bananeros logran Acuerdos El Raizón,” El Nuevo Diario, 21 March 2004.

135 Luis Felipe Palacios, "Bolaños apoyará con abogados a los del Nemagón," La Prensa, 21 March 2004.

136 Joaquín Tórrez A., "Ex bananeros logran Acuerdos El Raizón,” El Nuevo Diario, 21 March 2004.

137 José Adán Silva, "Víctimas del Nemagón, se van y esperan no volver," La Prensa, 22 March 2004.

138 José Adán Silva, "Procurador no viajará a Ginebra," La Prensa, 27 March 2004.

139 José Adán Silva, "Gobierno garantiza llevar caso Nemagón a la ONU," La Prensa, 26 March 2004.

140 Valeria Imhof, “Admiten demanda Nemagón en EU,” El Nuevo Diario, 21 April 2004.

141 Lucía Navas, "Otra esperanza para víctimas del Nemagón," El Nuevo Diario, 14 April 2004.

142 Máximo Rugama Castillo, "En veremos acuerdos con víctimas del Nemagón," El Nuevo Diario, 3 May 2004.

143 Máximo Rugama Castillo, "700 daños del Nemagón en Estelí,” El Nuevo Diario, 8 July 2004.

144 David M. Goldstein, The Spectacular City: Violence and Performance in Urban Bolivia (Durham, NC: Duke University Press, 2004), 18.

145 Silvia E. Carrillo, "Víctimas del Nemagón 'a la Buena de Dios'," El Nuevo Diario, 1 September 2004.

146 Silvia E. Carrillo, "Niegan cirugías a víctimas de Nemagón," El Nuevo Diario, 26 November 2004.

147 José Adán Silva, “Afectados por Nemagón piden dinero para salud," La Prensa, 14 December 2004.

148 José Adán Silva, "Víctimas del Nemagón amenazan con regresar," La Prensa, 4 January 2005.

149 José Adán Silva, "Nueva march de los afectados por Nemagón," La Prensa, 3 February 2005.

150 Roberto Pérez Solís, "No todos los afectados por Nemagón van a protestar," La Prensa, 19 January 2005.

151 José Adán Silva, "Mañana inicia marcha de Occidente," La Prensa, 19 February 2005.

152 Marianela Flores Verga, "Inicia otro viacrucis de afectados con Nemagón," El Nuevo Diario, 22 February 2005.

153 José Adán Silva, "Dole no negociará nada del Nemagón,” La Prensa, 3 March 2005.

154 José Adán Silva, "Ex bananeros indignados," La Prensa, 4 March 2005.

155 Arnulfo Agüero and Haydée Brenes F., "Víctimas de Nemagón otra vez burlados," El Nuevo Diario, 3 March 2005.

156 José Adán Silva, "Ex bananeros indignados," La Prensa, 4 March 2005.

157 José Adán Silva, "Campesinos desconfían de repentino apoyo Sandinista," La Prensa, 7 March 2005.

158 José Adán Silva, “Caso Nemagón será denunciado ante la CIDH,” La Prensa, 8 march 2005.

159 José Adán Silva, "Ex bananeros se enterrarán," La Prensa, 9 March 2005.

160 Sílvia E. Carrillo, "Víctimas del Nemagón planean quemarse vivos," El Nuevo Diario, 10 March 2005. 


\section{Ethan Grundberg}

161 Anne Pérez Rivera, "Piden retiro de la 'docena sucia'," La Prensa, 12 March 2005.

162 Esteban Solís R., "Que no lo dude nadie, nos vamos a pegar fuego," El Nuevo Diario, 15 March 2005.

163 José Adán Silva, “Ex bananeros divididos por sus lídres,” La Prensa, 16 March 2005.

164 Juan C. Bow, “¡Por fin acuerdos con víctimas del Nemagón!” El Nuevo Diario, 19 March 2005.

165 Arnulfo Agüero, “Atención masiva a los del Nemagón,” El Nuevo Diario, 23 March 2005.

166 Arnulfo Agüero, “Nemagón convirtió en 'malditos' a los genes," El Nuevo Diario, 1 April 2005.

167 José Adán Silva, “Dole propone arreglo en caso del Nemagón,” La Prensa, 29 March 2005.

168 José Adán Silva, "Piden aclaración ante propuesta de Dole,” La Prensa, 31 March 2005.

169 José Adán Silva, “Ex bananeros ocupan edificio de la PDDH,” La Prensa, 8 April 2005.

170 José Adán Silva, "Campesinos se enfilan en contra de los diputados," La Prensa, 15 April 2005.

171 Anne Pérez Rivera, "Harán champa solidaria con ex bananeros," La Prensa, 26 April 2005.

172 José Adán Silva, "Ex bananeros planean contactar a Michael Moore," La Prensa, 18 April 2005.

173 Anne Pérez Rivera, "Desmontan protesta de los ex bananeros," La Prensa, 14 May 2005; Lucía Navas and Octavio Enriquez, "Vuelven a casa los del Nemagón," El Nuevo Diario, 14 May 2005.

174 Sylvia Hernández E., "Pedirán a CIDH ayude a afectados del Nemagón," El Nuevo Diario, 23 May 2005.

175 Carol Munguía, "Llegan los primeros del Nemagón a EE.UU.," La Prensa, 21 July 2005.

176 Valeria Imhof, "Sentencia favorece a víctimas del Nemagón," El Nuevo Diario, 12 August 2005.

177 José Adán Silva, “Una Esperanza en caso Nemagón,” La Prensa, 27 August 2005.

178 Luis Felipe Palacios, "Diputados al fin se deciden a apoyar a ex bananeros," La Prensa, 21 September 2005.

179 “Los del Nemagón regresan mañana a sus comunidades," El Nuevo Diario, 8 October 2005.

180 José Adán Silva, "Dole se defenderá contra causas del pesticida Nemagón,” La Prensa, 23 July 2005.

181 José Adán Silva, "Ex bananeros en nuevo conflicto por pasaportes," La Prensa, 6 July 2005.: Anne Pérez Rivera, “Denuncia contra líder Nemagón,” La Prensa, 17 October 2005.

182 Maria Haydee Brenes, “Afectados por Nemagón intentan acercamiento,” El Nuevo Diario, 19 October 2005.

183 Carlos Amorín, "Los damnificados negocian directamente con las empresas," <http://www. rel-uita.org/agricultura/agrotoxicos/nemagon/con_victorino_espinales.htm> (18 October 2005).

184 José Adán Silva, "Dole se defenderá contra causas del pesticida Nemagón," La Prensa, 23 July 2005.

185 José Adán Silva, “Querella en Colombia por caso Nemagón,” La Prensa, 19 July 2005.

186 Anne Pérez Rivera, “Abogan por pension para ex bananeros,” La Prensa, 13 May 2005.

Ethan Grundberg graduated in December 2005 with majors in history and international studies and a minor in political science. He spent a year volunteering for an English, eco-tourism, and rural development project in rural Nicaragua and is now living in New York City, where he works on the Brooklyn community garden field staff for the New York Restoration Project. Ethan will begin a master's program in international agricultural development at the University of California at Davis beginning this September. 